\title{
AC 2007-2693: DESIGNING A COURSE ON BUSINESS PROCESS REENGINEERING (BPR): BRIDGING THE GAP BETWEEN BUSINESS OPERATIONS AND ENGINEERING OF SYSTEMS
}

\section{Rashmi Jain, Stevens Institute of Technology}

RASHMI JAIN is Associate Professor of Systems Engineering at Stevens Institute of Technology. Dr. Jain has over 15 years of experience of working on socio-economic and information technology (IT) systems. Over the course of her career she has been involved in leading the implementation of large and complex systems engineering and integration projects. Dr. Jain is currently the Head of Education and Research for International Council of Systems Engineering (INCOSE). Her teaching and research interests include systems integration, systems architecture and design, and rapid systems engineering. Dr. Jain is Head of Education and Research of INCOSE. In this role she is leading the development of a reference Systems Engineering curriculum. She holds Ph.D. and M.S. degrees in Technology Management from Stevens Institute of Technology.

\section{Ozgur Erol, Stevens Institute of Technology}

Ozgur Erol is a PhD Student in Systems Engineering and Engineering Management at Stevens Institute of Technology. Her research interests include systems integration process evaluation, management and improvement. She received her bachelors and masters degrees in Industrial Engineering from Istanbul Technical University, Turkey and her MBA degree from Saint Joseph's University, Philadelphia, PA. She has worked in several information technology and organizational reengineering projects prior to joining the $\mathrm{PhD}$ program at Stevens.

\section{Anithashree Chandrasekaran, Stevens Institute of Technology}

ANITHASHREE CHANDRASEKARAN is a Doctoral Candidate in Systems Engineering and Engineering Management at Stevens Institute of Technology. Her research interests includes Rapid Systems Development and its processes, Development process reengineering, Risk Management and Modeling, System Integration, System Design and Architecture. She obtained her B.E. in Electrical and Electronics Engineering from P.S.G. College of Technology, India. She obtained her M.S. in Systems Engineering from Stevens Institute of Technology. She is a member of INCOSE. 


\title{
Designing a course on Business Process Reengineering (BPR): Bridging the Gap between Business Operations and Engineering of Systems
}

\begin{abstract}
:
Business Process Reengineering (BPR) is a systematic approach to helping an organization analyze and improve its processes. All systems are designed, developed and engineered to support business processes. Therefore, an understanding of the business processes for engineering students is crucial to choosing how to build and manage systems. BPR was an important activity 1990s and there is a dramatic re-emergence of organizations' interest in the topic ${ }^{1}$.
\end{abstract}

At Stevens Institute of Technology we, at the under graduate program in Engineering Management felt the need to provide our students the bridge between the design and engineering of systems and business operations. As a result, the primary author was involved in the design, development, and now, the teaching of this course in the senior year. This paper will share the experiences of the author in designing such a course, its relevance to the engineering management undergraduate students, and future benefits to the potential employers of these undergraduate students. The course was offered in the Fall of 2006 for first time to the senior year Engineering Management students.

Business Process Reengineering targets to achieve quantum improvements by rethinking and redesigning the way that business processes are carried out with the help of information technology (IT) as the primary facilitator. To remain competitive in today's global economy, there is an urgent need to rethink and transform the existing business processes for improved quality and efficiency, reduced costs, and increased profitability. This provides an opportunity to view the organization-wide processes from a systems perspective. A systems perspective focuses on looking at a set of problems as a whole and the context that creates the holistic view rather than looking at a set of problems as individually isolated events. The course called Business Process Reengineering - EM435 at Stevens is specially tailored to this need; it provides knowledge about BPR and its main concepts, the technologies and the strategies for implementing business transformation, and best practices on BPR. It emphasizes the role of BPR in managing technology and the engineering functions. The course covers the strategic, operational and technological aspects of BPR by relating it to quality improvement and Information Technology. It introduces the main concepts underlying the transformation of business processes, explains the enabling role of IT, and demonstrates the application of different tools to the redesign of business processes.

The major learning objectives of the EM435 course are:

- To understand the importance of processes and BPR and appreciate how BPR bridges the business operations and engineering of systems.

- To understand how business processes can be radically improved, dramatically reducing process cycle time and cost, and improving the quality of the process products or outcomes.

- To identify business processes that are candidates for improvement 
- To model current business processes and diagnose problems

- To model and develop improved business processes that require IT and organizational redesign

- To develop measures and benchmarks for business processes

The pedagogical strategy of the course is to combine the lecture style of teaching and in-class case discussions. Each lecture starts with a presentation of major concepts underlying the subjects to be covered by the instructor and accompanied with in-class discussion of the case studies related to these concepts. The course also provides the students with the success and failure factors of BPR through the case studies. This facilitates the students' ability to relate the course topics to real-world context. The course is designed to teach students BPR methodologies and the modeling technique that accompanies the methodology. The students are required to apply the concepts covered in the class to a real-life process to analyze, model, and optimize it in their final team projects.

The implementation of BPR (EM 435) course at the undergraduate level was assessed using the Stevens' School of Engineering assessment system designed to evaluate the educational outcomes of various undergraduate engineering programs. The Course Outcomes Assessment process at Stevens includes a two-pronged approach - the course survey and the Student Performance Assessment (SPA). In this paper we focus on the SPA approach of course assessment. Since the course was taught for the first time it makes sense to focus on the appropriateness of the content as demonstrated by student learning in their assignments, exams, and the final project.

\section{Introduction}

The curriculum of Engineering Management (EM) program at Stevens Institute of Technology emphasizes the integration of management, human, and technology (i.e., systems) issues. The goal of the EM program is to produce graduates who can work effectively at the interface between technology, management, and engineering ${ }^{2}$. Educational programs need to be able to meet the challenges of accelerating change and complexity in today's business and technology environments by graduating students who are well-equipped with holistic business management and IT skills that meet the market needs and the expectations of their employers ${ }^{3}$. In order to better support the need for providing the bridge between the design and engineering of systems and business operations, the Stevens EM Program introduced the Business Process Reengineering - EM435 course within its curriculum. This paper explains the design, development and teaching of this course in the senior year. This paper will share the experiences of the primary author in designing such a course, its relevance to the engineering management undergraduate students, and future benefits to the potential employers of these undergraduate students. The course was offered in the Fall Semester of 2006 for the first time to the senior year Engineering Management students.

BPR is a systematic approach to helping an organization analyze and improve its processes. This provides an opportunity to view the organization-wide processes from a systems perspective. A systems perspective focuses on looking at a set of problems as a whole and the context that creates the holistic view rather than looking at a set of problems as individually isolated events. 
All systems are designed, developed and engineered to support the business processes within an organization. Therefore, an understanding of the business processes is crucial for engineering students for making decisions on designing, building, and managing systems. BPR was an important activity 1990s and there is a dramatic re-emergence of organizations' interest in the topic $^{1}$. A survey conducted by a reputable consulting firm of 960 companies published in 2005 confirmed this trend. The use of BPR as a management tool was reported to have gone down from 69 percent in 1995 to 38 percent in 2000, and revived again to 61 percent in $2004^{1}$.

The concept of reengineering traces its origins back to management theories developed as early as the nineteenth century. BPR integrates methods from total quality management, technology and innovation management, strategic planning, systems engineering, and organizational design ${ }^{4}$. The Stevens EM program has been offering courses related to these topics and integrating BPR in the curriculum was only natural. It aimed to provide our students an understanding of the BPR as a concept, learning of the tools and techniques and the ability to find similarities and differences between total quality management and information technology and business operations.

BPR was first introduced as a concept for getting radical improvements and better business results by Michael Hammer in 1990 5, 6,7 followed by James Champy, Thomas Davenport and several others in the literature ${ }^{8,9,10,11}$. Since its initiation it has become a popular management tool for dealing with technological and business changes in the competitive environment. BPR was widely used and accepted from 1993 to 1997 however a downturn in its usage started around the late nineties due to unaccomplished and unrealistic expectations. However there is a reemergence of interest in the topic since 2002 and as of 2004 BPR became as popular as in mid $1990 \mathrm{~s}^{1}$. In the later years, the authors who pioneered in publishing on the BPR related topics or the practitioners who have applied BPR programs revisited the subject and evaluated the claims which appeared in the earlier publications ${ }^{12,13,14}$. This second generation literature discussed the pros and cons of BPR concepts, provided insights for success and failure factors and most importantly revealed the unrealistic expectations and misconceptions from the concept admitting what was missing in the earlier literature. For example, Michael Hammer's confession appears in a Wall Street article late in 1996 stating that he reflected his engineering background but failed to appreciate the human dimensions of the reengineering programs ${ }^{15}$. Even why the criticism of the topic was on the rise, researchers and authors continued to synthesize the success and failure factors of BPR, looked for the development of new tools and techniques, and emphasized organizational and human aspects of BPR. As a result of all these efforts, BPR matured as a management and engineering tool. As evidenced by a recent multi-industry, multi-national survey ${ }^{1}$, this new interest in BPR is being accelerated by global competition. As one company becomes dramatically more productive, others in the industry must follow. But what distinguishes most of today's projects from the reengineering boom of the nineties is that they are enabled by large information technology efforts. And the Internet has made technology an even more important enabler of process change ${ }^{16}$.

Today BPR is a mature concept which has evolved in time and which is supported by extensive literature. This literature is a result of various academicians' and practitioners' valuable work and thoughts on the subject. When we planned to add BPR to our EM curriculum, we had no doubt that BPR was a topic which was backed by stable and mature material worthy of being taught. 
Before we developed the course, we extensively reviewed BPR related literature. At the same time we also did a survey on how BPR is being taught in other universities and programs. Our survey revealed that BPR related courses are mainly taught at the graduate level business programs (MBA programs), and undergraduate and graduate level Information Systems (IS and MIS) programs. (This information is based on the publicly available course syllabi for these programs). These courses either emphasize the business and organizational aspect of the topic or are built from a very technical perspective. However, we realized that in order to do justice to the topic we had to emphasize both the business and technical aspects of BPR. BPR uses information technology (IT) to radically change or redesign the business processes within organizations to dramatically increase their efficiency and effectiveness. There are five essential elements that define BPR: (1) BPR consists of radical or at least significant change; (2) BPR's unit analysis is the business process; (3) BPR tries to achieve major goals or dramatic performance improvements; (4) IT is a critical enabler of BPR; and (5) organizational changes and human issues are critical enabler of BPR and must be managed accordingly ${ }^{16}$. We built our BPR course around these five elements and specially tailored our curriculum to address the need to produce EM graduates who can work effectively at the interface between technology, management, and engineering.

\section{The Stevens BPR Course}

The BPR course provides knowledge on BPR and its main concepts; the technologies and the strategies for implementing business transformation; and best practices on BPR. It emphasizes the role of BPR in managing technology and the engineering functions. The course covers the strategic, operational and technological aspects of BPR by relating it to quality improvement and Information Technology. It introduces the main concepts underlying the transformation of business processes, explains the enabling role of IT, and demonstrates the application of different tools to the redesign of business processes.

The major learning objectives of the course are:

- To understand the importance of processes and BPR, and appreciate how BPR bridges the business operations and engineering of systems.

- To understand how business processes can be radically improved, dramatically reducing process cycle time and cost, and improving the quality of the process products or outcomes.

- To identify business processes that are candidates for improvement

- To model current business processes and diagnose problems

- To model and develop improved business processes that require IT and organizational redesign

- To develop measures and benchmarks for business processes

Often, the employers of our undergraduate students have mentioned to us that our students are technically very sound but they need more help in applying the technical knowledge and skills for solving real problems. Our course objectives have focused on creating the required awareness amongst the EM majors of the role of understanding the underlying business processes in order to undertake any technological redesigns and improvements. Identifying business processes that are suitable for improvements, analyzing the problems, selecting 
optimization techniques, and benchmarking them - these are skills that are extremely helpful for our students in all kinds of analyst roles that they begin their careers with.

\section{BPR Course Implementation - Pedagogy and Content}

The topics to be covered in this course were selected to address the major course objectives. The course was offered for a sixteen-week semester and planned around thirteen lectures. The content for each of the topics covered in the course is listed below:

1. Introduction to Fundamentals of BPR: This is the first week's introductory lecture which aims to introduce students to the concept of BPR. This lecture included definitions of process, process types and hierarchies, components of process architectures, the need for understanding processes, and its relation to business performance. Throughout the lecture, the discussions and questions are designed to guide students to think about the reasons of inefficiency in processes. The students also had the opportunity to read and discuss in class the historical articles on BPR - how it evolved as a concept and later practiced by many organizations.

2. BPR: Concept of "As-Is to To-Be": This lecture aims to provide students how process analysis and improvement can be achieved with BPR emphasizing the 'As-Is' to 'To-Be' concepts. This lecture starts with a brief history of process analysis and improvement, and builds the discussion around process analysis and improvement opportunities, process analysis approach, process life cycle, and process analysis and improvement tasks. A simple business process improvement and analysis example is used in class to demonstrate to the students the tasks associated with analysis and improvement. Students are also required to select a simple business process and try to analyze and improve it as a weekly in-class assignment.

3. Process Management \& Improvement: "Evolutionary Change vs. Revolutionary Change": This lecture covers process management and improvement tools including Six Sigma, Total Quality Management (TQM) and other process management and improvement methods. The difference between these methods and BPR is emphasized by explaining BPR's revolutionary approach while others are evolutionary. Class discussion on a business case which explains the differences between the evolutionary and the revolutionary approaches helped students understand and decide when and how BPR should be used.

4. Business Process Design Framework: This lecture presents an eight-step business process design framework based on process modeling and simulation. This framework provides students a systematic approach which they can apply to reengineering of processes. The framework consists of eight steps including case for action and vision statement; process identification and selection; obtaining management commitment; evaluating design enablers; acquiring process understanding; creative process design; process modeling and simulation, and implementation of the new process design.

5. Business Process Tools and Techniques I: This lecture is designed to teach students graphical tools, and workflow design principles and tools used for business process 
analysis. Some of the graphical tools which are covered in this lecture include general process charts, process activity charts, process flow diagrams, flow charts. Workflow design principles and tools such as establish product orientation in the process, eliminating buffers, one-at-a-time processing, balancing bottleneck flows, minimizing sequential processing and handoffs, scheduling based on job characteristics and minimizing multiple paths are also covered in this lecture.

6. Business Process Tools and Techniques II: This lecture builds upon the tools and techniques taught in the previous lecture. It further extends to include the use of software for applying these tools and techniques in BPR. Students get familiar with the evolution of process mapping tools and associated symbols. They learn to use Visio as a Process Improvement Tool. A hands-on session is included on mapping the process they have selected using Visio.

7. Business Process Measurement: This lecture aims to teach students the importance of process measurement and emphasizes that the future improvement opportunities can only be based on measured processes.

8. Business Process Modeling \& Simulation I: A simulation based business process design framework is selected and introduced to students in this course. This lecture is designed to teach students how modeling and simulation can be used for analyzing the existing (As-Is) processes and designing improved (To-Be) processes. Since students have already taken an introductory course on simulation and modeling, this lecture does not intend to teach modeling and simulation but rather focuses on why and how it is used for business process reengineering and improvement. Students learn that conceptual process designs need to be tested before they are implemented in full scale. Business processes are often too complex and dynamic to be analyzed only with simple tools like flowcharts and spreadsheets. Discrete event simulation is a powerful and realistic tool to complement the more simplistic methods. This lecture also emphasizes that simulation provides faster and cheaper testing of the improved or reengineered processes.

9. Business Process Modeling \& Simulation II: This lecture builds upon the general discussion of the previous lecture. Students are introduced to Extend software for process modeling and simulation. Extend is a simulation software which can be used to simulate discrete-event or continuous systems. It has a BPR specific tool called BPR library created for the purpose of modeling and simulation of business processes. Students have an in-class hands-on session where they get an opportunity to apply what they have learnt. They were given a business process problem to simulate and model.

10. Business Process Benchmarking Using Best Practices: This lecture's objective is to teach students the concept of benchmarking and its importance for reengineering and improvement of business processes. The lecture covers the definitions and types of benchmarking. It provides real life examples on companies' use of benchmarking and resulting achievements. Students also read and discussed a benchmarking related case study. 
11. Success and Failures of Business Process Reengineering: This lecture aims at integrating all the learning objectives of this course by discussing the success and failure factors of $\mathrm{BPR}$. The lecture covers findings of various researches on BPR success and failure factors.

\section{Course Material}

The students used various course materials throughout the semester. Two textbooks were selected as the main text and were supported with class lecture notes prepared using PowerPoint slides, case studies and articles from credible sources. The materials were made available to the students on secure web. The students also uploaded their assignments through the same interface.

Each of the topics was introduced by the instructor in the class through lectures using PowerPoint presentation. Students were asked to also read the relevant chapter associated with each of the lectures covered in the class. Extensive use of participative-student-centered teaching style was used by having students work in teams on cases studies, articles and readings, and business process simulation software exercises. The cases were then discussed by the instructor around certain key questions and the teams were asked to address these questions. The case studies and readings were based on real experiences of companies in applying BPR. Team and individual 'take-home' assignments were also given to intensify the experience of learning from real-life case studies and readings, and by discussing them in a participative manner with the students in the class.

\section{Final Team Project}

The final team project is an important part of the BPR course. The students form into teams to work on this project which starts from the first week and is presented on the last day of the class. The scope of the project was introduced in the beginning of the semester.

The purpose of the project is to provide students with an opportunity to develop a deeper understanding of business process design and reengineering and apply the concepts to a real life problem.

The final project focuses on the design and redesign of a business process in a specific setting in which the students have had some experience or interest. Each student team selects one business process. Students also need to define the parameters for the business project that they propose to study. This final project gives the student the chance to identify a reengineering opportunity within an organization and to analyze the "As-Is" situation and define and redesign the "To-Be" situation.

To define the business process, the students need to identify a specific organization and have adequate access to information about the business process. Once having identified an organization, and a business process, students are required to develop a process for base lining the business process (often referred to as "process mapping"), and redesigning it. The general learning objective is to provide the students an opportunity to do business process reengineering on a real-life process. 
The reengineering project consists of two main parts. Part I of the project focuses on selecting, understanding and modeling the business process (As-Is Process). Part II focuses on reengineering and implementation (To-Be Process).

The teams work on the final project during the semester. Teams are required to submit two status reports as they advance and complete the required steps though out the semester. Teams submit a final report and present their project in class.

\section{Course Assessment}

The implementation of BPR (EM 435) course at the undergraduate level has been assessed using the Stevens assessment system. The assessment system that has been implemented by the Charles V. Schaefer Jr. School of Engineering at Stevens Institute of Technology ${ }^{17}$ is designed to evaluate the educational outcomes of various undergraduate engineering programs.

Each engineering program has established a set of program objectives developed in concert with the various constituencies of that program such as alumni, employers, faculty, students, etc., and are subjected to periodic assessment to ensure their continued relevance. In order to meet the program objectives, a set of program outcomes and relevant course outcomes has been established. These outcomes range from the technical, such as knowledge and application of science and engineering science as well as design competencies, to so-called "soft skills" such as relating to effective teamwork, communication skills, ethics, life-long learning, etc. Program outcomes are used to ensure that the program curriculum is aligned with the program objectives. The program outcomes are linked to the School of Engineering-level Curriculum Outcomes ${ }^{18}$. The outcomes of all programs are also designed to be consistent with the requirements of Criteria 3 of ABET Engineering Criteria 2000.

The Course Outcomes Assessment process at Stevens includes a two-pronged approach - the course survey and the Student Performance Assessment (SPA). The course survey solicits students' opinions on their perception of how significant was their learning experience in the course with respect to the Course Outcomes. The course outcomes for business process reengineering (EM 435) and their mapping with the program outcomes, curriculum outcomes and ABET criteria are provided in Table 1. The course outcomes are a direct reflection of the course objectives. This table shows how the outcomes of EM 435 is directly tied with the engineering management program outcomes and the ABET criteria.

In this paper we focus on the SPA approach of course assessment. Since the course was taught for the first time it makes sense to focus on the appropriateness of the content as demonstrated by student learning in their assignments, exams, and the final project. The next section will discuss this in more detail. 
Table 1 EM435 Course Outcomes and its mapping

\begin{tabular}{|c|c|c|c|}
\hline \multicolumn{4}{|c|}{ I. BROAD BASED TECHNICAL EXPERTISE } \\
\hline $\begin{array}{l}\text { School of Engineering } \\
\text { Curriculum Outcomes }\end{array}$ & ABET & Program Outcomes & EM 435 Outcomes \\
\hline $\begin{array}{l}\text { 2. (Engineering } \\
\text { foundations) the ability to } \\
\text { use applied scientific } \\
\text { knowledge }\end{array}$ & $\begin{array}{l}\text { 3.e. an ability to } \\
\text { identify, formulate, } \\
\text { and solve } \\
\text { engineering } \\
\text { problems) } \\
\end{array}$ & $\begin{array}{l}\text { be able to analyze systems using an } \\
\text { engineering management approach. }\end{array}$ & $\begin{array}{l}\text { (2) Model and develop } \\
\text { improved business } \\
\text { processes that require } \\
\text { IT and organizational } \\
\text { redesign }\end{array}$ \\
\hline $\begin{array}{l}\text { 3. (Experimentation) the } \\
\text { ability to design } \\
\text { experiments, conduct } \\
\text { experiments, and analyze } \\
\text { experimental data }\end{array}$ & $\begin{array}{l}\text { 3.b. an ability to } \\
\text { design and conduct } \\
\text { experiments, as well } \\
\text { as to analyze and } \\
\text { interpret data }\end{array}$ & $\begin{array}{l}\text { be able to design, conduct and analyze } \\
\text { experiments through the use of } \\
\text { engineering economics analysis, } \\
\text { statistical, life cycle and IPPD models, } \\
\text { probability applications and word } \\
\text { problems that use examples from } \\
\text { manufacturing or service applications. }\end{array}$ & $\begin{array}{l}\text { (3) Model current } \\
\text { business processes and } \\
\text { diagnose problems }\end{array}$ \\
\hline $\begin{array}{l}\text { 4. (Technical design) the } \\
\text { technical ability to design a } \\
\text { prescribed engineering } \\
\text { subsystem }\end{array}$ & $\begin{array}{l}\text { 3.c. an ability to } \\
\text { design a system, } \\
\text { component, or } \\
\text { process to meet } \\
\text { desired needs }\end{array}$ & $\begin{array}{l}\text { be able to determine the scientific and } \\
\text { engineering management variables of } \\
\text { interest and processes to manage } \\
\text { engineering design alternatives and } \\
\text { management planning. }\end{array}$ & $\begin{array}{l}\text { (4) Identify business } \\
\text { processes that are } \\
\text { candidates for } \\
\text { improvement }\end{array}$ \\
\hline $\begin{array}{l}\text { 5. (Design assessment) the } \\
\text { ability to develop and } \\
\text { assess alternative system } \\
\text { designs based on technical } \\
\text { and non-technical criteria } \\
\end{array}$ & |- & $\begin{array}{l}\text { be able to assess the ergonomic, } \\
\text { economic, social and environmental } \\
\text { requirements, needs and constraints of } \\
\text { the system and its impact on the global } \\
\text { society. }\end{array}$ & $\begin{array}{l}\text { (5) Develop measures } \\
\text { and benchmarks for } \\
\text { business processes }\end{array}$ \\
\hline $\begin{array}{l}\text { 6. }(\text { Tools }) \text { an ability to use } \\
\text { the relevant tools necessary } \\
\text { for engineering practice }\end{array}$ & $\begin{array}{l}\text { 3.k. an ability to use } \\
\text { the techniques, } \\
\text { skills, and modern } \\
\text { engineering tools } \\
\text { necessary for } \\
\text { engineering practice }\end{array}$ & $\begin{array}{l}\text { be able to use computational tools and } \\
\text { management software and theories for } \\
\text { finding graphical, statistical and } \\
\text { analytical solutions to problems } \\
\text { necessary for the practice of } \\
\text { engineering management. }\end{array}$ & $\begin{array}{l}\text { (6) Use a process } \\
\text { mapping software }\end{array}$ \\
\hline \multicolumn{4}{|c|}{ I. PROFESSIONAL ADVANCEMENT AND COMMUNICATIONS } \\
\hline $\begin{array}{l}\text { 7. (Professionalism) the } \\
\text { ability to recognize and } \\
\text { achieve high levels of } \\
\text { professionalism in their } \\
\text { work }\end{array}$ & $\begin{array}{l}\text { 3.f. an understanding } \\
\text { of professional and } \\
\text { ethical responsibility }\end{array}$ & $\begin{array}{l}\text { be able to use engineering management } \\
\text { analysis and TQM to develop } \\
\text { production plans and effective task } \\
\text { breakdowns and project plans based on } \\
\text { life cycle, material and information } \\
\text { processes and customer feedback of a } \\
\text { product, service or system. }\end{array}$ & $\begin{array}{l}\text { (7) Understand how } \\
\text { business processes can } \\
\text { be radically improved, } \\
\text { dramatically reducing } \\
\text { process cycle time and } \\
\text { cost, and improving the } \\
\text { quality of the process } \\
\text { products or outcomes }\end{array}$ \\
\hline $\begin{array}{l}\text { 10. (Communication) the } \\
\text { ability to communicate } \\
\text { effectively and } \\
\text { persuasively }\end{array}$ & $\begin{array}{l}\text { 3.g. an ability to } \\
\text { communicate } \\
\text { effectively }\end{array}$ & $\begin{array}{l}\text { be capable of submitting periodic oral } \\
\text { and written progress reports as well as } \\
\text { final written and oral reports on the } \\
\text { entire project and be capable of } \\
\text { critiquing and evaluating such. }\end{array}$ & $\begin{array}{l}\text { (10) Create a project } \\
\text { plan that implements a } \\
\text { new business process }\end{array}$ \\
\hline \multicolumn{4}{|c|}{ III. WORLDVIEW AND PERSONAL DEVELOPMENT } \\
\hline $\begin{array}{l}\text { 14. (Entrepreneurship) } \\
\text { have a fundamental } \\
\text { knowledge and an } \\
\text { appreciation of the } \\
\text { technology and business } \\
\text { processes to nurture new } \\
\text { technologies from concept } \\
\text { to commercialization. }\end{array}$ & |-- & $\begin{array}{l}\text { be able to understand the items } \\
\text { necessary to get a product, process or } \\
\text { service from conception to } \\
\text { marketplace. (design, project } \\
\text { management, sources of capital, } \\
\text { intellectual property, marketing, } \\
\text { principles of Quality). }\end{array}$ & $\begin{array}{l}\text { (14) Learn the } \\
\text { importance of } \\
\text { processes and BPR and } \\
\text { understand what BPR } \\
\text { can do for } \\
\text { organizations }\end{array}$ \\
\hline
\end{tabular}




\section{Performance Assessment}

Student Performance Assessment is a key component of the Stevens assessment process, because it is the only "direct" assessment method. That is, it is the only assessment based directly on students' work, rather than on surveys of students' perception of their learning or other indirect results. Data from both student work including assignments, exams etc. as well as surveys on students' perception of their learning are used by individual instructors for continuous course improvement.

The performance assessment was based on the work of the students throughout the semester. The class comprised of 18 students. Data on each of these students' demonstration of learning and knowledge through class participation, class discussions, individual and team assignments, midterm exam and the team project was included to evaluate the SPA. The level of students' performance for the entire class demonstrated through the above mentioned activities is provided below:

$\begin{array}{ll}\text { Class participation and discussions } & 62 \% \\ \text { Team assignments } & 97 \% \\ \text { Individual Assignments } & 83 \% \\ \text { Midterm Exam } & 76 \% \\ \text { EM 435 Team Project } & 92 \%\end{array}$

\section{Mapping of Course Outcomes with Student Performance}

The course learning outcomes as listed in Table 1 were mapped to the assignments, midterm and team project to evaluate and assess the level of student learning of the concepts of BPR. There were at least one or more course learning outcomes associated with each class assignment and midterm. Overall the student performance in midterm, assignments, and final team projects reflect an effective dissemination of the course content and objectives leading to an improved understanding of the BPR concepts. The assessment of the learning outcomes based on student performance in the assignments and midterm is shown in Figure 1 and Figure 2 respectively. The numbers representing course learning outcomes on the $\mathrm{x}$-axis in these charts are mapped and explained in the Table 1.

\section{Performance on Assignments and Midterm}

The students demonstrated a good understanding on "the importance of processes and BPR and what BPR can do for organizations", and "to model current business processes and diagnose problems". The students did not seem to have done very well in understanding "how business processes can be radically improved, dramatically reducing process cycle time and cost, and improving the quality of the process products or outcomes". As a result we observed lowest scores on these learning outcomes. In addition there were wide variations among individual students' learning on this outcome. This can be attributed to a combination of factors. Application of BPR tools in improving processes and products requires some knowledge of the functioning of a real organization. The students varied in their level of experience of working in 
organizations. This may have lead to some students finding it difficult to relate to the concepts covered in the course content to address this outcome.

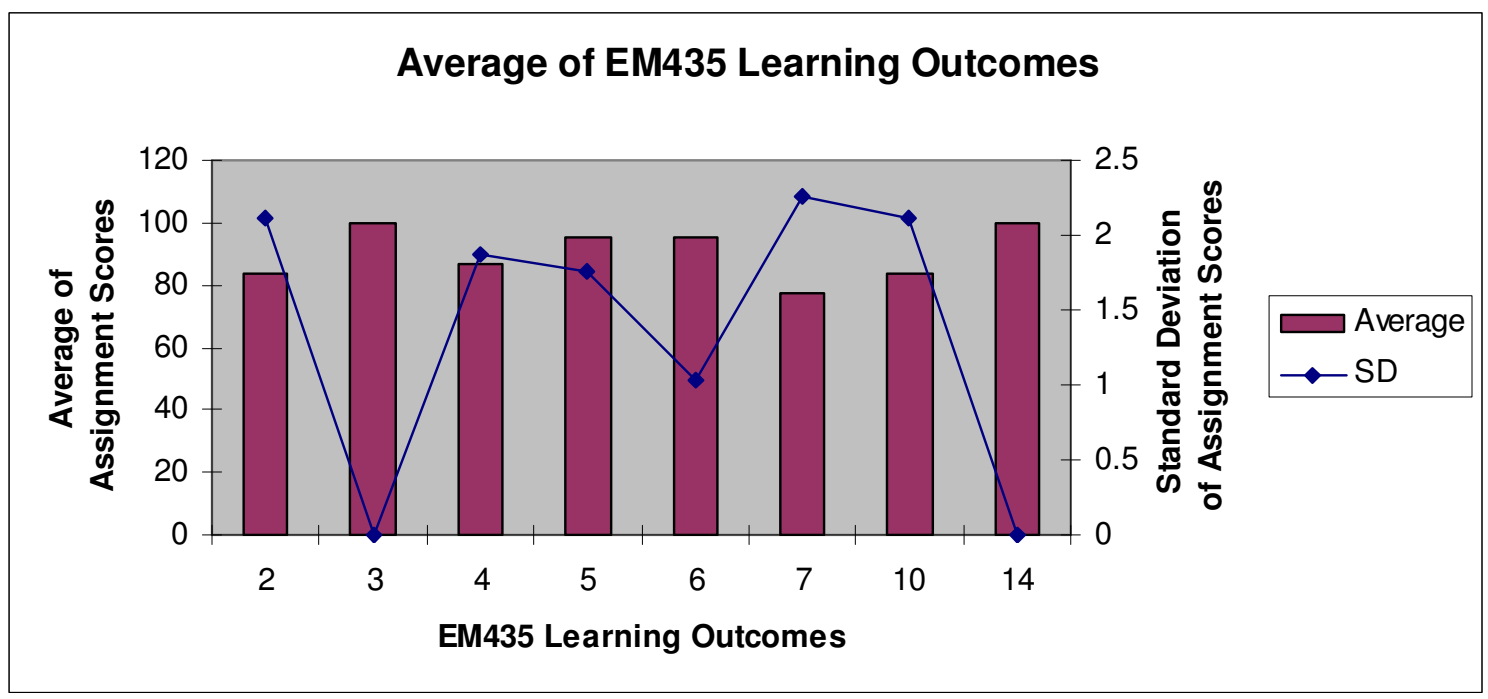

Figure 1 Course learning outcomes across student assignments

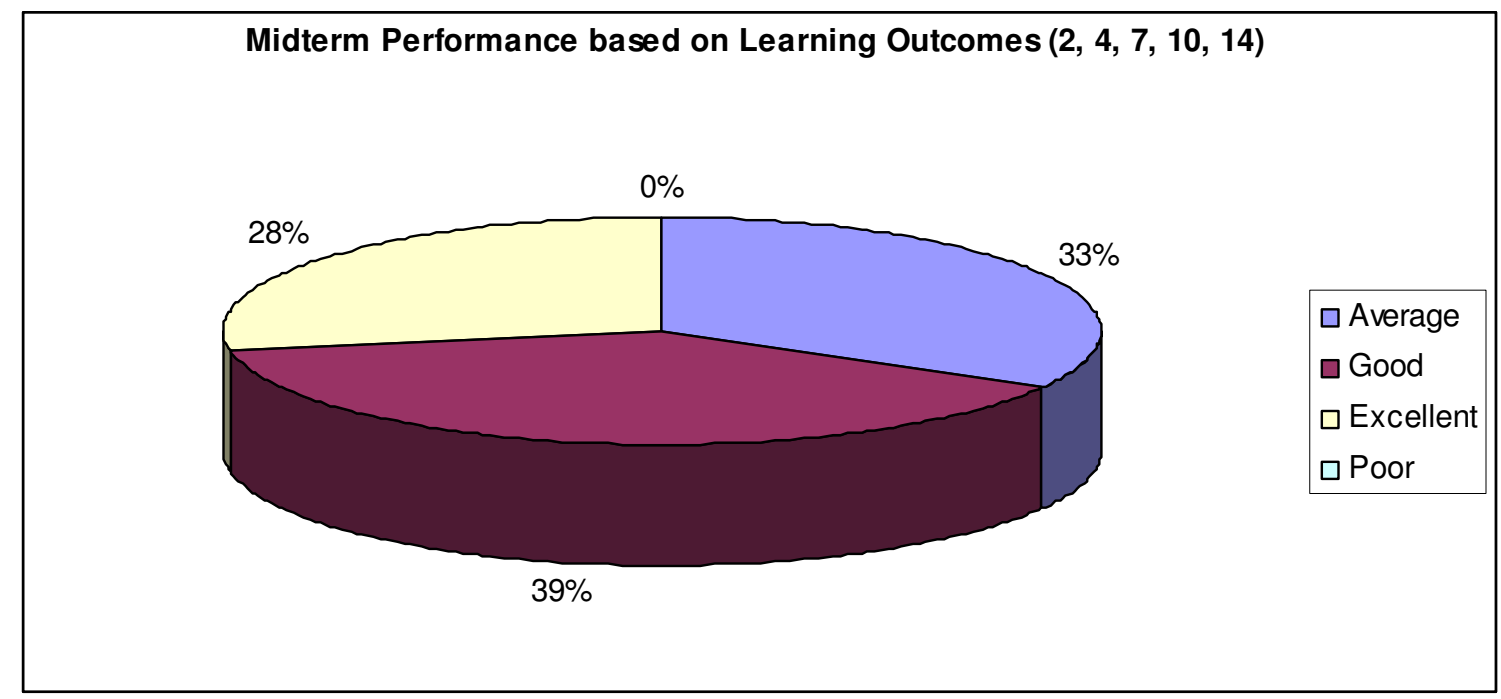

Figure 2 Midterm performance based on learning outcomes

\section{Performance on Final Team Projects}

The final team projects, described earlier in the paper in section called "Final Team Project", were assessed based on a pre-determined criteria developed to reflect the application of BPR concepts covered throughout the course. Each of these criteria was then mapped with at least one or more of the course learning outcomes to assess the student learning. The assessment of the learning outcomes based on student performance in their final team projects is shown in Figure 3. 
The student teams' performance on the final project was consistent with our earlier findings on their performance on the assignments and the midterm. Our findings were reconfirmed in the overall lower scores on all the outcomes in the final team projects. This is a clear indication that the students failed to relate the concepts of BPR covered in the course to applying to a real organization. Lack of work experience and exposure to the functioning of an organization restricted the student teams' ability to apply the concepts to the final team projects.

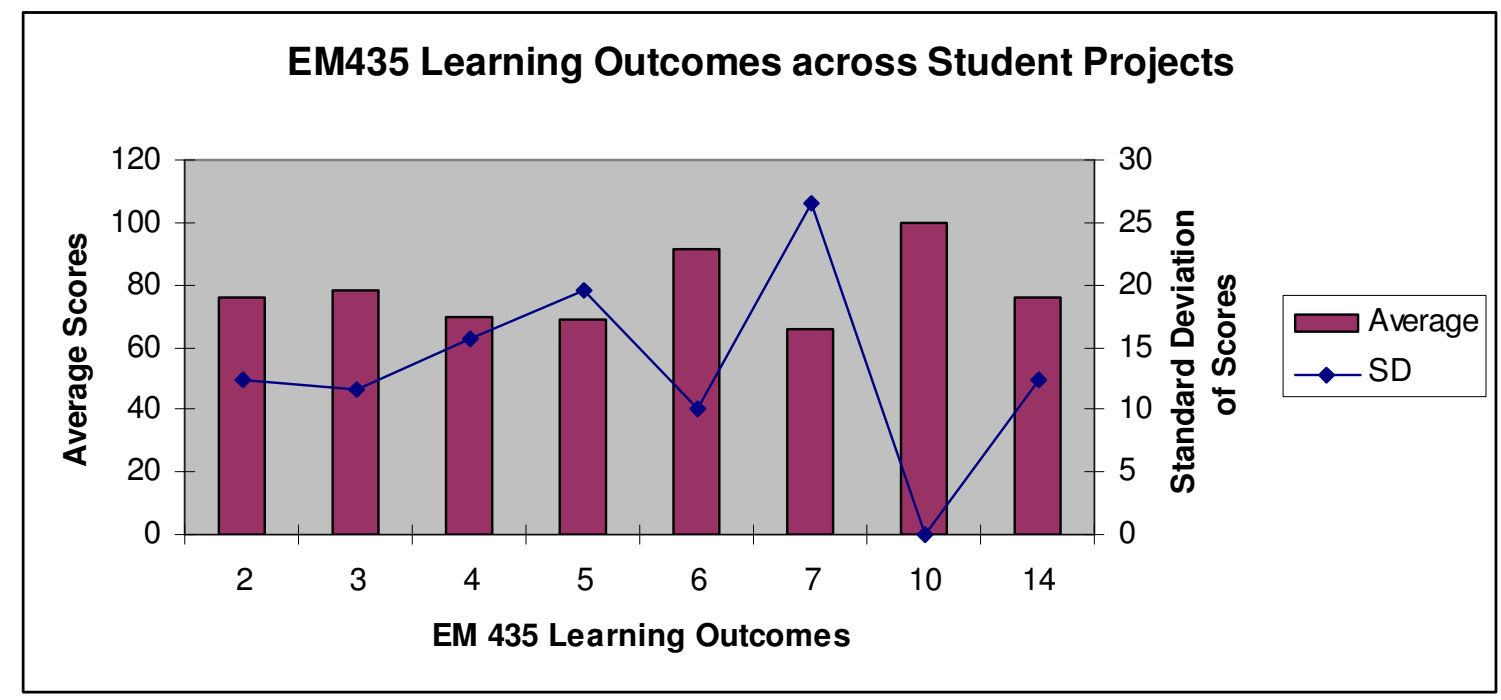

Figure 3 Course learning outcomes across student projects

\section{Conclusions}

Overall, it has been a very satisfying experience for us to understand the needs of the potential employers of our EM majors, to explore the need for BPR, research on the topic, and develop and teach this new course. The course will evolve over the semesters based on instructor experience and student feedback. So far, it seems that the students enjoy the use of software tools for doing flowcharting, simulation, and optimization analysis of business processes. This is reflected in the team assignment performance where the students did their best. Most of the team assignments were based on use of tools. It is also evident that teaming helped learning in this course. Since the course was focused on analysis the students found team and final project experience very useful.

We are going to be modifying the course based on the first time teaching in the last semester. More class time needs to be allocated to software based exercises. One important finding for us has been the students' inability to apply the BPR concepts to real organizational situations. This has been discussed in detail in the 'Performance Assessment' section. There is a definite need to provide more help and support to the students to be able to relate to real organization situations and be able to apply the BPR concepts covered in the course. This was also evident in the fact that the students also seem to need more help in identifying and approaching their final project. We have to find the right balance between making the students learn the realities of the real world and still not find it overwhelming within the requirements of their course work. As always it remains a challenge to define a perfect scope of a new course. 


\section{Acknowledgement}

The authors acknowledge the help and support of Dr. John Farr, Head of the Department of Systems Engineering and Engineering Management, Stevens Institute of Technology, in the development of the course on Business Process Reengineering and including it as part of the Engineering Management curriculum of the Institute.

\section{References}

1. Rigby, D.; Bilodeau, B. (2005). The Bain 2005 Management Tool Survey; Strategy \& Leadership; 2005; Vol. 33, Number 4; pg. 4.

2. Farr, J.; Sauser,B.J.; Jain, R.; Verma, D. (2005). Engineering Management Education - Technology Integration, Manufacturing, or the Management of Engineers and Scientists?

3. Al-Shammari M. (2005). Assessing the learning experience in a business process re-engineering (BPR) course at the University of Bahrain.; Business Process Management Journal; 2005; 11, 1; pg. 47.

4. Winter, R. (2002). An Executive MBA Program in Business Engineering: A Curriculum Focusing on Change; Journal of Information Technology Education, Volume 1 No. 4; 2002

5. Hammer, M. (1990). Reengineering Work: Don't Automate, Obliterate; Harvard Business Review, July August, 1990.

6. Hammer, M.; Champy, J. (1993). Reengineering The Corporation. A Manifesto for Business Revolution; Harper Collins Publshers, 1993.

7. Hammer, M.; (1996). Beyond Reengineering: How the Process-Centered Organization Is Changing Our Work and Our Lives, New York: HarperCollins Publishers, Inc., 1996.

8. Champy, J.; (1995). Reengineering Management: The Mandate for New Leadership, New York: HarperCollins Publishers, Inc., 1995.

9. Davenport, T.; Short, J. E.; (1990). The New Industrial Engineering: Information Technology And Business Process Redesign Sloan Management Review. Summer 1990. Vol. 31, Iss. 4; p. 11.

10. Davenport, T. (1993). Need radical innovation and continuous improvement? Integrate process reengineering and TQM; Planning Review; 0094-064X, May-June 1993 v21 n3 p6(7).

11. Davenport, T. H.; (1993). Process Innovation: Reengineering Work through Information Technology, Harvard Business School Press, 1993.

12. Davenport, T., H.; (2003). Reengineering Revisited; Computerworld, June 2003; Vol. 37, No. 25.

13. Hammer, M.; (2005). CIO Evolution: To avoid extinction, CIOs must move from an orientation that revolves around technology to one centered on business processes; CIO; Aug 1, 2005.Vol.18, Iss. 20; pg. 1

14. Champy, J.; Weger, J.; (2005). Reengineering: the second time around; Strategy \& Leadership. Chicago: 2005. Vol. 33, Iss. 5; p. 53

15. White, J., B.; (1996). Next Big Thing': Re-Engineering Gurus Take Steps to Remodel Their Stalling Vehicles - Michael Hammer and Others Broaden Their Offerings, Push Growth Strategies - Two Days for 'People Issues'; Wall Street Journal.; Nov 26, 1996; pg. A.1.

16. Ahadi, H., R.; (2004). An Examination of the Role of Organizational Enablers in Business Process Reengineering and the Impact of Information Technology; Information Resources Management Journal; Oct-Dec 2004; Vol. 17, No. 4.

17. Charles V. Schaefer Jr. School of Engineering at Stevens Institute of Technology, http://www.soe.stevens.edu.

18. Jain, R., Gallois, B., Chandrasekaran, A.; "Introducing 'Total Design' in an engineering design curriculum: A Pilot Experience", ASEE Conference Proceedings, 2006. 